\title{
The Differentiation of Products and Opportunity for Intra-Industry Exchange
}

\author{
Jean-Sylvain Ndo Ndong ${ }^{1}$ \\ ${ }^{1}$ Faculty of Law and Economics, Omar Bongo University, 680, avenue Léon Mba, B.P. 3886 Libreville - \\ Gabon \\ Correspondence: M. Jean-Sylvain Ndo Ndong, Faculty of Law and Economics, Omar Bongo University, \\ 680, avenue Léon Mba, B.P. 3886 Libreville - Gabon.
}

Received: July 16, 2020

doi:10.5539/ibr.v13n9p88
Accepted: August 13, $2020 \quad$ Online Published: August 20, 2020

URL: https://doi.org/10.5539/ibr.v13n9p88

\begin{abstract}
The financial crisis of the late 2000s gave rise to protectionist hints which called into question the consensus on the liberalization of world trade since the creation of the World Trade Organization (WTO) in 1995. This trend towards protectionism has taken on new magnitude with the arrival of Donald Trump as President of the United States of America. In fact, since the beginning of 2018, the American administration has carried out its threats by imposing customs duties on imports of the various products from China and the European Union. In retaliation, the countries concerned responded with restrictions on American exports to their territory. Also the rationality of the market economy, there is more and more opposed the power of emotions and impulses embodied by the populists at the head of which D. Trump, the American President. Globalization is therefore required to adapt its rules to survive.

The purpose of this paper is to show that for a good adaptation of its rules, it is necessary to activate one of the most powerful levers of gains in international trade, the differentiation of products. This is a response to the exploitation of the diversification and heterogeneity of demand in terms of tastes and incomes. Because, by allowing the firm to differentiate its products to distinguish them from those of competitors, differentiation offers the opportunity to soften competition, increase profits and improve product quality.
\end{abstract}

Keywords: competition, differentiation, economies of scale, exchange, intra-industry trade, globalization, opportunity, protectionism, similarity

\section{Introduction}

Is product differentiation a source of intra-industry trade? This question finds a beginning of answer with the seminal works of Krugman (1979) which renew the theory of international trade. And the principle of comparative advantage on which this theory is based is, however, the most general and powerful economic argument for demonstrating the interest of international exchange and specialization, as Samuelson and Stolper (1941) point out.

The problem is that this principle, often against intuitive because of the difficulty of getting it admitted, hardly justifies that relations between nations of unequal economic and technological power, can be mutually beneficial. It is unfortunately easier to explain that such an exchange is made up of gains and losses since the most powerful are always the winners and the weakest, the losers. Moreover, it is this understanding that leads to the idea of economic war and protectionism justified by the defense of national production and employment not only by the weakest, but also by the so-called strong nations.

The classical theory of international trade, based on the principle of technological (Ricardo, 1817) or factorial (Heckscher, Ohlin and Samuelson, 1919) differences between countries, does not accept that beneficial trade can take place between similar countries. This theory is based on assumptions of perfect competition and constant returns to scale. It has remained very limited in its explanation of world trade. World trade is an exchange of primary products for goods that are part of an industrial process (Siroën, 1991).

However, since the late 1970s, this theory has incorporated the contributions of industrial economics, such as increasing returns to scale, product differentiation, firm strategies, etc., into its analyses, hence the birth of what has come to be known as the new theory of international trade or "the theory of international trade in imperfect 
competition" (Krugman, 1979). This theory provides new explanations for international trade in terms of demand characteristics (Linder, 1961; Lassudrie-Duchêne, 1971) or, above all, supply and market structure, with the hypotheses of pure and perfect competition being abandoned in favor of monopolistic competition; intra-industry trade is considered to be an exchange of differentiated products $\left(\right.$ Calmette, 1993) ${ }^{1}$. Economies of scale are now seen as a source of gain in exchange. They thus replace comparative advantages in classical theory.

Today, international trade is under more threat than ever before. While open trade policies had been the norm since the creation of the WTO in 1995, the 2008-2009 crisis marked a turning point in this process. The trend towards protectionism that it fostered took on a new dimension with the arrival of Donald Trump as President of the United States of America. And since the beginning of 2018, the US administration has implemented several of its threats of trade protectionism through the introduction of tariffs on imports of various products. There have been trade restrictions on around 12\% of imports from the United States of America. At the same time, $6 \%$ of its exports were affected by retaliatory measures. The rationality of the market economy is now opposed to the power of emotions and impulses embodied by US President D. Trump and the populists. To survive, globalization must adapt its rules.

One of the adaptations is to activate one of the most powerful levers of gains in international trade, product differentiation which seems to be a response to exploiting the diversification and heterogeneity of demand in terms of tastes and incomes (Mekki, 2005). It is presented as a company policy that consists in differentiating its products to distinguish them from those of its competitors. It allows:

- to direct the consumer's purchase towards the company's products thanks to their brand image or their specific characteristics;

- to incite the consumer to buy goods by giving them particular attractions that those of competitors do not have;

- to reduce competition by eliminating the possibility of direct comparison between the various products on the market ;

- to confer monopoly power on the firm since it is the only one to produce the differentiated good ${ }^{3}$.

There are various types of product differentiation. The first is horizontal differentiation. Horizontal differentiation is based on a number of non-hierarchical characteristics that are not perceived in the same way by consumers, such as the color of a shirt or the taste of a wine. It is precisely the diversity of these tastes and colors that leads producers to multiply models within a given product range. Horizontal differentiation is the result of consumers' preference for variety.

Then there is vertical differentiation. It consists of a set of attributes that can be measured. This is the case of the power of a car engine. When these attributes (characteristics) can be similarly assessed by consumers, the goods are prioritized. For example, a fast, powerful, comfortable and robust car will be preferred by all consumers to another low-end car. Between the two, there is a vertical differentiation.

Companies compete by producing horizontally and vertically differentiated goods, both domestically and internationally. Consumers' search for differentiation leads them to buy foreign goods if they have characteristics that are considered different from those offered on the domestic market. This gives rise to cross-trade in similar products between countries that can be identified by intra-industry trade flows.

Two approaches explain intra-industry trade:

$1^{\circ}$ ) Linder's (1961) representative demand approach, according to which production conditions in a country depend on demand conditions ;

$2^{\circ}$ ) the product differentiation approach, which stipulates that the products of the same industry are not identical.

${ }^{1}$ The term "intra-industry trade" refers to imports and exports of similar products between countries, i.e. products in the same industry.

${ }^{2}$ As the products are no longer identical on the market, their prices are no longer directly comparable. The comparison must now be made on the basis of a "quality-price" ratio, which is difficult to establish because quality is often subjective and rarely quantifiable. Differentiation thus makes it possible to reduce price competition.

${ }^{3}$ Differentiation transforms perfect competition into monopolistic competition and allows for higher prices. Monopolistic competition means a market structure in which each supplier has a particular product that is not directly comparable with those of other companies. 
They are heterogeneous in their attributes, even if their utility is the same. They differ in color, advertising, packaging, image, after-sales service.

According to Lassudrie-Duchêne (1971), consumer demand is a demand for differences in similarity: agents demand a set of characteristics of a good.

However, if products in the same industry differ in the characteristics offered, it is possible that an American consumer who wants a car may be attracted to a Chinese car, because the characteristics of that car correspond better to his or her needs than those of American cars. The development of intra-industry trade would then come from the heterogeneity of goods within the same industry. The existence of international trade is therefore explained not so much by differences in prices (and therefore in production costs), but by product differentiation and then by strategic research, quality, marketing and advertising policies. Structural competitiveness then supplants price competitiveness.

Leaving aside the limitations of measurement methods, it would appear that intra-industry manufacturing trade has grown significantly since the late 1980s in many OECD countries. This followed a trend increase in intra-industry trade in all major OECD economies between 1970 and 1990.

In the case of the least developed countries, with similar levels of development, they do not necessarily have the opportunity to offer manufactured goods. While the traditional theory of international trade excludes, by its construction, the possibility of trade between these countries, in particular because of their similar structures, the new theory, on the other hand, offers them the opportunity to build exchanges of similarities (Ndo Ndong, 2000). This is the case of a Senegalese consumer who wants a piece of wooden furniture. He may well be attracted by a piece of furniture made of wendjé or movengui ${ }^{4}$, species available in the Gabonese forest, whose characteristics correspond better to his needs than those of furniture made of Sahelian wood or liana.

Indeed, differentiation strategies, whether they concern products or customers, enable the company to increase its market share and improve its profitability. This provides it with the financial means for future growth. More than ever before, therefore, they present themselves as an opportunity for all countries to develop intra-industry trade: either by offering different characteristics of an apparently homogeneous product, or by marketing a product with a recognized high (or low) quality, provided that the infrastructure in these different countries allows firms (SME/SMI) to benefit from economies of scale.

The purpose of this contribution, which is intended as a theoretical reminder, is to show that all protectionist gestures are unnecessarily costly, as in the case of the trade war waged by the American administration against products from all directions (Chinese, European, etc. $)^{5}$. In this respect, we would like to recall that product differentiation can allow any country, wherever it is and whatever it is, to open up without worrying too much about any price competitiveness on its part.

This study is therefore structured as follows: the second section leads us to present the literature not only on product differentiation but also on the link between differentiation and intra-industry trade. The third section presents the differentiation model. The fourth section invites some comments on the results and finally the fifth section is reserved for the conclusion of the study.

\section{The Literature Review}

This literature review will first focus on fundamental approaches to differentiation before turning to the link between differentiation and intra-industry exchange.

\subsection{Basic Approaches to Product Differentiation}

The economic literature distinguishes two canonical approaches to product differentiation. Spatial approaches, still referred to as "address-based" models, on the one hand, and representative consumer approaches or "unaddressed" models on the other.

\subsubsection{Spatial Approaches to Product Differentiation}

The present approach, inspired by the work of Hotelling (1929) and Lancaster (1966, 1975, 1979 and 1980), is

\footnotetext{
${ }^{4}$ Wendjé and movengui are two very strong wood species that are very resistant to weather and weevils. Wendjé wood is printed with designs that add to the ornament of the furniture. The wood of movengui is homogenous and yellowish in color.

${ }^{5}$ In his December 6, 2019 publication, Eric Le Boucher states that "Mr. Trump's protectionism has cost households and has not created any of the jobs he was tweeting.
} 
based on a so-called horizontal differentiation; it is particularly concerned with product specification. For this approach, it is the location of firms in a market that interests the authors.

In reality, this is the case of a market in which firms sell an identical product, but where there are transport costs to make the good available to consumers.

This approach enables Hotelling to study the optimal location of each firm along a straight line of finite length, making assumptions about the geographical distribution of customers and the mobility of firms once a sales outlet has been chosen.

To this end, Hotelling conducts its analysis on both the demand side and the supply side of differentiated goods.

On the demand side first of all, it considers a heterogeneity of consumer preferences. For him, this is the basis for differentiated goods.

Then, on the supply side, the firm differentiates its products by exploring increasing internal economies of scale.

Thus, Hotelling argues that spatial differentiation is one in which the location of a sales market is a criterion for differentiation. However, the results to which it leads, remain very sensitive to the hypotheses adopted: linear transport costs, identical product, purely spatial differentiation, etc. The results of the model are not yet available. Nevertheless, the contribution of the Hotelling model is more of an analogy between localization and product differentiation, as Barberis (2000) believes. Hotelling himself has suggested an extension of his model from localization in space to localization in a set of varieties of an asset.

With the rise of the "new consumer theory" or the "theory of characteristics", Lancaster (1966, 1971 and 1975) explored new directions for Hotelling's idea. All of this work was part of a monopolistic competition approach in which each firm produced a single variety in the presence of increasing internal economies of scale. For Lancaster, goods are bundles of characteristics, not entities. These goods lie within a spectrum at equal distances from each other, with equal market shares. Similarly, consumer preferences are spread across this spectrum in a uniform manner. Lancaster thus assumes a spatial distribution of consumer tastes in the continuous space of product characteristics. In other words, each consumer has his or her own preferences for an "ideal variety" that determines his or her address in this space.

However, it should not be forgotten that firms incur fixed costs that limit their offer to one variety per firm. Thus, the degree of competition between firms is directly related to the degree of differentiation of the products they offer, in other words, to the degree of proximity of their varieties in the characteristics space. This competition will take place between two firms offering similar varieties (substitute varieties).

Lancaster's contribution to the literature on product differentiation is more than interesting for two reasons:

1- A model integrating product differentiation, the diversity of consumer tastes and increasing returns to scale. But this modeling excludes from the analysis any strategic interaction between firms, neglecting the reactions of the competition. Moreover, the structure of perfect monopolistic competition is a theoretical framework that simplifies reality and does not take into account the heterogeneity of firms.

2- Taking into account the contributions of the industrial economy in an open economy provides other explanations for the structure of international trade, in this case it explains intra-industry trade by product differentiation and consumer preferences.

In one extension of Hotelling's model, Salop (1979) adopts Lancaster's (1966) conception of differentiation by characteristics and proposes a circular version of spatial competition. He considers that consumers and firms are uniformly distributed over a circular space of characteristics as opposed to the linear city of Hotelling. He assumes that consumers bear a quadratic transport $\operatorname{cost}^{6}$. While highlighting product characteristics and spatial competition between firms, Salop's modelling is limited to local competition. But Salop finds the symmetry of the equilibrium of the Hotelling model with equal prices. This symmetry can be explained by the static framework of the entry game he adopts. In this dynamic version of the circular model, Eaton and Lipsey (1978) show, in a sequential entry game that equilibrium prices do not tend towards the competitive price and that firms can make positive profits in the long run.

Hotelling's principle of minimal differentiation has been criticized by several economists, including D'Aspremont, Gabszewicz and Thisse (1979). These show that if firms differentiate their products by choosing

\footnotetext{
${ }^{6}$ Under this hypothesis, each firm is in direct competition with its two close neighbours in the circular space. Its demand depends solely on the prices of these two firms and does not take account of the reactions of $\mathrm{n}$ firms on the market.
} 
fixed locations at fairly distant locations, they avoid increased price competition and make clearly positive profits.

To ensure the existence of a price equilibrium, these authors consider a quadratic form of the transport cost borne by consumers as a function of the distance separating them from the firm's location. Instead, they have opted for a principle of maximum differentiation with the existence of an uncooperative price equilibrium, whereas at Hotelling, when the locations are close together, the firm offering the lowest price will be able to benefit from the rival firm's demand. It is therefore no exaggeration to consider, with Gabszewicz and Thisse (1980), that maximum product differentiation is a means of escaping price competition.

The principle of maximum differentiation by quality was also presented by Gabszewicz (2000) in a context of vertical differentiation. Through his model, which incorporates an oligopolistic market structure, he assumes that market entry of a higher quality product leads to lower prices for lower quality products. In other words, only firms offering superior quality products, i.e. innovative firms, remain on the market.

In this oligopolistic market framework, Shaked and Sutton $(1982,1983)$ proposed a series of models where, at equilibrium, the number of varieties is limited by income distribution and consumer preferences. Thus, vertical product differentiation can be said to be relative to an oligopolistic rather than monopolistic market structure.

\subsubsection{The Representative Consumer Approach}

This approach is based on Chamberlin's (1933) model, which first introduced the notion of differentiation into economic analysis. Product differentiation according to this approach is called vertical differentiation; it relates to the quality of the product

Under the hypothesis of increasing returns, Chamberlin considers that each firm offers a variety with unique characteristics on the market. And it is these characteristics that have the ability to build consumer loyalty. Thus, by differentiating its product from that of its competitors, each firm puts itself in a monopoly position and, from this point of view, can face a function of increasing demand.

Dixit A. and J. Stiglitz (1977) have taken up Chamberlin's conclusions in the same way as P. Krugman (1979), who developed them to introduce consumer preferences for variety. In fact, market demand incorporates an aggregate preference for diversity which generates demand for varieties.

For Krugman, firms bear the same production costs regardless of the variety produced.

The utility function of the representative consumer depends on the quantity consumed of variety $i$ as well as the degree of substitution between goods. When the representative consumer maximizes his utility under his budget constraint, the assumption of free entry leads to zero equilibrium profits

Some criticisms related to the symmetry of supply and demand conditions have been directed at the presentation of the representative consumer's behavior:

On the one hand, under the assumption of the production of substitutable goods, firms bear identical production costs and do not choose their degree of differentiation from other products ;

On the other hand, consumer preferences are symmetrical under the assumption of constant elasticity of substitution. On the other hand, consumer preferences are symmetrical under the assumption of constant elasticity of substitution. And if we assume symmetry of supply and demand with respect to each variety produced, we find the same type of equilibrium as in Chamberlin's basic model:

varieties are produced in the same quantity, sold at the same price and profits are zero at equilibrium.

These criticisms are more profound when Geweke (1985) questions the logic of the representative consumer. Indeed, he considers that when the parameters of the model are changed, the reaction function of the representative consumer fails to accurately reflect the reaction function of all the consumers he represents. In his view, it is better to separate individual behavior from collective behavior insofar as these two behaviors cannot have the same reactions.

7 The origin claimed by Chamberlin for its analysis of differentiation is linked to the work it conducted in 1921 in its studies of the heavy goods rail pricing debate. This work included a discussion of product homogeneity and the entire analytical apparatus subsequently developed by the author.

${ }^{8}$ This is the classic result of the neo-Chamberlinian modeling of monopolistic competition. 


\subsection{Approaches Linking Product Differentiation and Intra-Industry Trade}

In general, work addressing product differentiation issues related to intra-industry trade is expressed in terms of both supply and demand and the nature and structure of markets.

The particularity of intra-industry trade is that it is linked to economies of scale. The notion of economies of scale is itself linked to imperfect competition (Linder, 1961; Negishi, 1975). To this end, Kojima (1970) considers that intra-industry trade is made possible by the rationalization of resources within multinational firms as well as by intra-firm trade (Mucchiell, 1977) .

Another explanation advanced in the literature on intra-industry trade is related to the product cycle. However, although this life-cycle theory took shape outside of the intra-industry literature, it has been perfectly adapted to this new framework (Grubel, Lloyd, 1975). And, as is well known, life cycle theory explains much of the trade in manufactured goods through the process of innovation and research and development. Since knowledge and information are neither free nor open, the product first appears in a single country. The momentary monopoly situation then enjoyed by the innovative country allows it to export the product and exploit foreign markets without direct competition. This lasts until the time comes, for various reasons, when the period of imitation by other countries begins. The product will then become commonplace, the innovative country will slow down its exports and even partially import this product and specialize in new products ${ }^{10}$.

On the other hand, it is easy to understand why monopolistic competition corresponds to the fact that within the same industry, innovations will come from different countries. To this end, several types of intra-industry trade are identified. A cross-exchange of two new products, or a new product against a mature product, or an exchange of two mature products.

Grubel and Lloyd also showed that the main causes of intra-industry trade could be antagonistic. Thus, through the economies of scale approach, they assume that the inputs of the different products traded in this cross-trade are almost similar in quantity and quality. Whereas through the product cycle approach, they base these exchanges on the availability of certain factors ${ }_{11}$ of production, such as skilled labor and Research and Development, for which new products are intensive .

Other studies linking differentiation and intra-industry trade relate to the role of demand or, more generally, to the structure and nature of the market.

The major contribution of this approach comes from the studies of Linder (1961), whose main concern is to explain that it is "representative domestic demand" that is the support, "the necessary but not sufficient condition" for a given good to become an exportable product.

For him, the external market is nothing more than the extension of the domestic market and international trade is nothing more than the extension of regional trade. In other words, the volume of trade between partners will be all the greater the closer the structure of their demand, since the importable of some may be exportable by others.

Analyses relating to market structure emphasize the influence of economic integration on the creation and increase of intra-industry trade. The authors of these analyses have in fact noted that the more integration between the various national markets takes place, the more intra-industry trade develops. Integration creates a larger and more homogeneous market, "stabilizing trade in manufactured goods and allowing the achievement of economies of scale" (Kojima, 1970), while bringing different national demands closer together ${ }^{12}$.

Explanations relating specifically to intra-product trade may also be of interest. Indeed, it is not superfluous to consider that there is intra-product trade because the goods analyzed are somehow differentiated.

\footnotetext{
${ }^{9}$ What needs to be understood is that the benefits of economies of scale can be realized through policies of "concerted specialization" among partners at the same level of development (Kojima, 1970).

${ }^{10}$ Every product thus goes through three phases in its evolution: the innovation phase, the growth phase and the maturity phase. Here, comparative advantage is based on a temporary technological advance, which is constantly being questioned, hence the notion of "dynamic comparative advantage" devised by H. Johnson (1968).

${ }^{11}$ Since in its innovation phase the product is intensive in skilled labor and in the other two phases it is intensive in capital and unskilled labor, it can be assumed that the product does not represent the same good in these different phases.

${ }^{12}$ These arguments are empirically confirmed, particularly in Europe, since European countries have the most intra-industry trade.
} 
For differentiations endogenous to the product, differentiations created by supply or demand can be observed.

In the first case, differentiation may come from the difference in quality offered, style, brand, products which, moreover, are identical in terms of their inputs and purpose. In addition to these quality differences, there may also be differences in actual or implied prices due to market imperfections.

As regards the second case, differentiation may arise from differences in consumer tastes, income, information ${ }^{13}$, etc. Linder (1961) uses the concepts of a product's degree of quality or sophistication. The more complex the products demanded, the higher the degree of sophistication. The structure of demand will cover a range of more or less sophisticated products, a range that overlaps to a large extent with that of countries with a comparable structure of demand.

In fact, the unlimited range of differentiated products makes it possible for trade to flourish in what is virtually the same commodity. This trade can be carried out on the basis of a demand for difference, as Lassudrie-Duchêne (1971) suggests.

We just have to understand that this type of trade is more developed for highly sophisticated products than for others, the quality levels being much higher for the former.

Differentiation related to phenomena outside the product can be of several kinds:

Two identical products can be differentiated in time (their availability will not exist at the same time) or in space. Their place of production will not be the same or the distance between the places of production, storage and consumption will not be the same. Among the manifestations of intra-product trade caused by this kind of differentiation are seasonal trade and re-export trade.

The various theoretical explanations relate to the existence of transaction costs, information costs, market viscosity, unavailability, oligopolistic structures and so on.

This differentiation may be accentuated by other distortions in market mechanisms and, in particular, by state intervention, taxation, export subsidies. For example, firms in one country may prefer to export and receive aid rather than operate their own internal market without state aid. If this system is found in several countries for the same products, trade will be cross-fertilized

\section{Presentation of the Differentiation Model}

Whether horizontal or vertical, product differentiation gives the firm monopoly power over its differentiated good. Faced with the multitude of varieties of goods on offer, economic agents value the consumption of each variety and demonstrate a need for maximum diversification ${ }^{15}$. Based on the work of Dixit and Stiglitz (1977), we present a simplified formalization of the differentiation model applied to intra-industry trade.

\subsection{Model Assumptions}

We imagine that in the equatorial forest there are different varieties of wood. There are stronger species and species that are less resistant to weathering and weevils. These varieties can be cross-traded. Because some wood species are more available in Cameroon than in Gabon and vice versa... The same distinctions can be observed in Sahelian wood varieties. Thus, attracted by characteristics related to the price, color and quality of the wood from which the table is made, a Gabonese consumer will prefer a table made of Sahelian wood and a Nigerian one, a table made of equatorial wood. Just as a Cameroonian would like to consume a South African wine on a table made of fir wood from Morocco.

By focusing exclusively on the African market for wooden tables, we consider that in this market, a multitude of companies belonging to the same branch are operating and competing with each other by producing a different variety of the same good. Each new firm entering the market therefore gets a share of this market at the expense of its competitors. There are no barriers limiting the entry of firms; entry continues until profits are extinguished. So we have a monopolistic competition structure where a very large number of monopolists compete fiercely against each other.

Opening up to trade gives agents the opportunity to consume all available varieties of goods from wooden tables (Sahelian wooden tables from Senegal, Mali, Burkina-Faso, etc., as well as equatorial forest wooden tables from

\footnotetext{
${ }^{13}$ Reflections on this subject are also addressed by Linder.

${ }^{14}$ It should just be remembered that several explanations for the intra-product are similar to those for the intra-industry, such as imperfect competition, technology, the role of demand, and so on.

${ }^{15}$ It is this love for variety that leads them to systematically consume all available varieties.
} 
Cameroon, Congo, Gabon, etc.). It can thus emerge from intra-branch African trade ${ }^{16}$. In other words, with openness, consumers have access to a greater variety of wooden tables, which in turn increases their satisfaction. Moreover, with the increase in demand elasticity for each firm, the intensification of competition resulting from openness will lead each firm to increase its production in order to exploit its economies of scale and thus reduce its costs and prices. A gain in production scale is then added to the gain in variety ${ }^{17 .}$

Four observations help us to understand the logic of firms:

1- Product differentiation means that most branches produce a large number of similar wooden tables, even if they can be considered as not identical;

2- Of all the possibilities open to firms, only a subset of varieties is actually produced ${ }^{18}$;

3- Industries that produce differentiated tropical wood tables often have a high concentration (those producing equatorial wood tables will be located in Congo, Gabon or Cameroon in particular; those interested in Sahelian woods will be more concentrated in Sahelian countries such as Mali, Senegal, Burkina-Faso, etc.);

4- Consumers buy only a relatively small subset of all available varieties of wooden tables.

Furthermore, it is considered that firms have an incentive to produce a wide variety of the same wooden table ${ }^{19}$, on the one hand, and this variety is a source of market power and therefore profit (hence the incentives), on the other hand.

We would like, for a better understanding, to limit the production of the branch to two tables made of wood from the equatorial forest (eq) and Sahelian wood (sh). They are therefore differentiated, i = eq, sh.

Let us start from the inverse demand functions of the following two wooden tables ${ }^{20}$ :

$$
\begin{gathered}
p_{e q}=\alpha-\beta q_{e q}-\gamma q_{s h} \quad \text { and } \\
p_{s h}=\alpha-\gamma q_{e q}-\beta q_{s h}
\end{gathered}
$$

$$
\text { with } \beta>0, \beta^{2}>\gamma^{2} \text {, }
$$

where $\mathrm{q}_{\mathrm{eq}}$ and $\mathrm{q}_{\mathrm{sh}}$ are respective quantities of tables in equatorial and sahelian wood and each table variety is produced by a single firm. We are therefore facing a duopoly.

Inequality implies that the effect on the $\mathrm{p}_{\mathrm{eq}}$ price of a variation in $\mathrm{q}_{\mathrm{eq}}\left(\mathrm{dq}_{\mathrm{eq}}\right)$ is greater than an identical variation in $\mathrm{q}_{\mathrm{sh}}\left(\mathrm{dq}_{\mathrm{sh}}\right)$. In other words, the own-price effect dominates the cross-price effect. That is, the variation in the quantities of equatorial wood tables has a greater impact on the price of equatorial wood table than the variation in the quantities of sahelian wood tables.

\subsection{Model Resolution}

Starting from relations (1) and (2) and after a few manipulations, we arrive at the following request functions:

$$
\begin{gathered}
q_{e q}=a-b p_{e q}+c p_{s h} \\
q_{s h}=a+c p_{e q}-b p_{s h} \\
\text { with } a \equiv \frac{\alpha(\beta-\gamma)}{\beta^{2}-\gamma^{2}}, b \equiv \frac{\beta}{\beta^{2}-\gamma^{2}}>0, c \equiv \frac{\gamma}{\beta^{2}-\gamma^{2}}>0
\end{gathered}
$$

\footnotetext{
${ }^{16}$ It is driven entirely by consumer preferences and firm differentiation strategies.

${ }^{17}$ Thus, the more countries produce differentiated goods, the more similar they are and the more their trade will be dominated by intra-industry trade.

${ }^{18}$ A wooden piece of furniture does not come in all colors and is not made with all types of wood.

${ }^{19}$ Even if they don't find the same number of buyers for each of them.

${ }^{20}$ We neglect production costs for the sake of simplicity. Indeed, some very solid wood species require finer (sophisticated) material to make a table. This could increase the average manufacturing cost compared to a very malleable wood species.
} 
The importance of differentiation corresponds to the weakness of the interdependence of demands. We will use this idea as a basis for imagining a measure of the degree of differentiation of the varieties of wooden tables. This gives:

$$
\delta=\frac{\gamma^{2}}{\beta^{2}}
$$

For example, when consumers think that wooden tables are very different, the demand functions are almost independent, $\gamma \rightarrow 0$ or $\delta \rightarrow 0$ so $c \rightarrow 0$.

But when they think that the table varieties are very close, the cross-price effect is of the same importance as the own-price effect $\gamma^{2} \rightarrow \beta^{2} \delta \rightarrow 1$ or $c \rightarrow b$.

In this case, we can consider that the varieties of wooden tables from the Sahel and those from the equatorial forest are almost homogeneous.

\section{Discussions and Comments}

The degree of differentiation in the industry can soften competition, just as it can improve product quality. Ultimately, it all depends on the firm's adjustment variable. Firms can compete either in terms of quantities or prices.

\subsection{In the Case of Competition by Quantity}

In the case of quantity competition, the Cournot duopoly model specifies that each firm tries to maximize its profit by taking into account the quantities released on the market by the competitor. Its program is as follows:

$$
\begin{gathered}
M a x / q_{e q} \prod_{e q}\left(q_{e q}, q_{s h}\right)=\left(\alpha-\beta q_{e q}-\gamma q_{s h}\right) q_{e q} \\
\frac{\delta \prod_{e q}\left(q_{e q}, q_{s h}\right)}{\delta q_{e q}}=\alpha-2 \beta q_{e q}-\gamma q_{s h}=0 \Rightarrow q_{e q}^{*}\left(q_{s h}\right)=R_{e q}\left(q_{s h}\right)=\frac{\alpha-\gamma q_{s h}}{2 \beta} . \\
\text { Thus } R_{e q}^{\prime}\left(q_{s h}\right)=\frac{-\gamma}{2 \beta} .
\end{gathered}
$$

The negative sign of $\mathrm{R}_{\mathrm{eq}}{ }^{\prime}\left(\mathrm{q}_{\mathrm{sh}}\right)$ means that quantities are not necessarily substitutable strategies. When differentiation is very weak, $\gamma$ increases and $\beta$ remains positive $(\beta>0)$. Thus, when $\gamma \leq 0$, the price of $\mathrm{i}$ increases, its quantities decrease with those of $\mathrm{j}\left(p_{i} \uparrow x_{i} \downarrow x_{j} \downarrow\right)$. The goods are then complementary.

In other words, if differentiation induces a complementarity between the two varieties, in other words, if the table in equatorial wood is complementary to the table in sahelian wood, the quantities can become complementary strategies.

But in the case of substitutability, $0 \leq \gamma \leq \beta$ the price of variety i rises, its quantities demanded fall and those

of variety $\mathrm{j}$ rise $\left(p_{i} \uparrow x_{i} \downarrow x_{j} \uparrow\right)$. These are substitutable goods. In this case, quantities are substitutable strategies. Cournot's equilibrium $\left(q_{e q}^{c}, q_{s h}^{c}\right)$ is therefore the solution of the system of equations :

$$
\left\{\begin{array}{l}
q_{e q}^{c}=R_{e q}\left(q_{s h}^{c}\right) \\
q_{s h}^{c}=R_{s h}\left(q_{e q}^{c}\right)
\end{array}\right.
$$

Taking into account the symmetry of the strategies, we will have for $\mathrm{i}=\mathrm{eq}$, sh 


$$
q_{i}^{c}=\frac{\alpha}{2 \beta+\gamma}, \quad p_{i}^{c}=\frac{\alpha \beta}{2 \beta+\gamma}, \quad \pi_{i}^{c}=\frac{\alpha^{2} \beta}{(2 \beta+\gamma)^{2}}
$$

Proposal: In the Cournot duopoly, increased differentiation $(\gamma \rightarrow 0)$ implies less sensitive reaction functions and higher profits.

$$
\frac{\delta \pi_{i}^{c}}{\delta \gamma}<0
$$

Differentiation therefore softens competition and thus improves the profits of firms ${ }^{21}$. From this point of view, it is incomprehensible that some governments advocate protectionism knowing that it is a more costly behavior for very weak results.

\subsection{In Case of Price Competition}

It should be noted that the quality of a wooden table can be appreciated in two different ways. On the one hand, by considering that the equatorial wooden table is of higher quality than the sahelian wooden table or vice-versa. On the other hand, it is possible to consider two equatorial (sahelian) wooden tables of different quality.

But in any case, the improvement of the quality of the differentiated wooden table is achieved through price competition.

Let us imagine a geometric location of the different qualities of a good. Based on the spatial model à la Hotelling (1929), we assume that each consumer expresses a different preference for the quality of the wooden table. This is uniformly distributed between a low, 0 preference and a higher, 1 preference for quality.

Let $\theta$ be the quality of the wooden table. It is assumed that this quality is between a lower level quality $\underline{\theta}$ and a higher-level quality $\bar{\theta}$ :

$$
\begin{gathered}
\theta \in[\underline{\theta}, \bar{\theta}], \\
\text { with } \theta>0 \text { et } \bar{\theta}-\underline{\theta}=1 .
\end{gathered}
$$

We therefore consider that the "typical" consumer buys a quality wooden table $\theta$ at price $\mathrm{p}$, and if $\mathrm{g}$ represents the taste for quality, its utility function is expressed as follows:

$$
U=\theta g-p
$$

Thus, the higher the taste for quality, $\mathrm{g}$, the higher the consumer's satisfaction. $\theta \mathrm{g}$ therefore represents the consumer's willingness to pay for quality $\theta$. The indifference curves can be represented as follows:

$$
\theta g-p=u_{0}<=>\theta=\frac{p}{g}+\frac{u_{0}}{g}=\frac{p+u_{0}}{g}
$$

And the existence of two firms (firm EQ and firm $\mathrm{SH}$ ) on the wooden table market, $(j=$ eq, sh) invites us to consider that Firm $\mathrm{j}$ produces the quality $\theta_{\mathrm{j}}$ with the quality of the table in equatorial wood superior to the quality of the table in sahelian one: $\theta_{\mathrm{eq}}>\theta_{\mathrm{sh}}$. The unit production cost for these two qualities of wooden table is $\mathrm{c}$.

Let $\mathrm{p}_{\mathrm{eq}}$ and $\mathrm{p}_{\mathrm{sh}}$ be the prices of the production factors. In order for firm SH, which produces the $\theta_{\mathrm{sh}}$ quality, to be able to sell its sahelian wooden table, it must offer it at a $p_{\text {sh }}$ price lower than the $p_{\text {eq }}$ price $\left(p_{\text {eq }}>p_{s h}\right)$. It can therefore be assumed that there is some segmentation of the market. Indeed, consumers with low incomes buy

${ }^{21}$ It can also be shown that with respect to price competition (Bertrand), the results are the same: differentiation softens competition (Dixit and Stiglitz, 1977). In the context of oligopolistic competition with free entry, it cannot be ruled out that less efficient firms may disappear from the international market. Only those firms that invest in research and development to improve the quality of their product will remain. Hence the need to choose the quality of the good that increases its profit. 
from firm SH and those with high incomes are attached to high quality. They therefore choose firm EQ. The whole problem is to know what the consumer who is indifferent to the quality of the table in question will choose.

We can locate the consumer who is indifferent between the two qualities of wooden table as long as they provide the same utility:

$$
\begin{aligned}
& g^{*} \cdot \theta_{e q}-p_{e q}=g^{*} \cdot \theta_{s h}-p_{s h} \\
& \Rightarrow g^{*}=\frac{P_{e q}-P_{s h}}{\theta_{e q}-\theta_{s h}}=\frac{P_{e q}-P_{s h}}{\Delta \theta} .
\end{aligned}
$$

The requests addressed to both firms are then:

$$
\begin{gathered}
D_{e q}\left(P_{e q}, P_{s h}\right)=g^{*}-\underline{g}=\frac{P_{e q}-P_{s h}}{\Delta \theta}-\underline{g}, \\
D_{s h}\left(P_{e q}, P_{s h}\right)=\bar{g}-g^{*}=\bar{g}-\frac{P_{e q}-P_{s h}}{\Delta \theta} .
\end{gathered}
$$

In other words, each firm maximizes its profit given its competitor's price. Profits can be written as follows:

$$
\begin{gathered}
\prod_{e q}\left(p_{e q}, p_{s h}\right)=\left(p_{j}-c\right) D_{j}\left(p_{e q}, p_{s h}\right), j=\text { eq, } s h \\
\prod_{e q}\left(p_{e q}, p_{s h}\right)=\left(p_{e q}-c\right) \cdot\left(\frac{p_{e q}-p_{s h}}{\Delta g}-\underline{\theta}\right) \\
\prod_{s h}\left(p_{e q}, p_{s h}\right)=\left(p_{s h}-c\right) \cdot\left(\bar{\theta}-\frac{P_{e q}-P_{s h}}{\Delta \theta}\right) \\
\prod_{e q}^{*}\left(p_{e q}, p_{s h}\right)=\left(\frac{\bar{\theta}-2 \underline{\theta}}{3}\right)^{2} \Delta \theta \\
\prod_{s h}^{*}\left(p_{e q}, p_{s h}\right)=\left(\frac{2 \bar{\theta}-\underline{\theta}}{3}\right)^{2} \Delta \theta
\end{gathered}
$$

Differentiation therefore softens competition in this case as well. We find Bertrand's profits when differentiation is zero.

Let us return to the choices of the quality of the wooden table by always considering the relation (5).

The results of the price game showed, on the one hand, that firms prefer as much differentiation as possible and, on the other hand, that each firm prefers to produce the highest quality.

Since Bertrand's profits are generally zero, firms always prefer to differentiate their product at equilibrium. There is nevertheless an indeterminacy as to which firm will produce the high quality since we have two Nash equilibria:

$$
\begin{aligned}
& \left\{\theta_{s h}=\underline{\theta} \text { et } \theta_{e q}=\bar{\theta}\right\}, \\
& \left\{\theta_{s h}=\bar{\theta} \text { et } \theta_{e q}=\underline{\theta}\right\}
\end{aligned}
$$

In both cases, the balance corresponds to the maximum differentiation. So even if the quality is not expensive, one firm prefers to produce the low quality when the other has already chosen the high quality.

Thus, when a firm has the opportunity to choose its quality before its competitor, it would choose the high quality and its competitor would choose the low quality in order to soften the price competition.

If the hypothesis $\bar{\theta}>2 \underline{\theta}$ is not verified, then the low-quality firm cannot survive in the market $\left(D_{s h}\left(p_{e q}^{*}, p_{s h}^{*}\right)=0\right)$. In this case, consumers do not have a strong enough desire for variety to support the existence of two different qualities on the market. Only one firm producing the high quality then exists.

This result is different from horizontal differentiation models because in the latter, any segment of the market is 
equivalent (in terms of demand) to any other. Regardless of the variety produced, consumers are only willing to buy the low quality if it does not cost too much. Thus the two segments (high and low) of the market are not equivalent.

In short, opening up to trade in the presence of vertical differentiation and a difference in income leads to a specialization of high-income countries (the United States, the European Union and Japan in particular) in high-quality goods and a specialization of low-income countries (emerging countries including China) in low-quality goods. However, in order to satisfy the heterogeneous consumer demand in both types of countries, a vertical type of intra-industry trade is being set up. Vertical intra-industry trade is thus explained by the strategy of vertical differentiation of firms associated with a differentiation of incomes and consumers' willingness to pay for quality.

\section{Conclusion}

Product differentiation is undoubtedly a source of intra-industry trade in so far as it can enable any firm to distinguish its product from that of its competitors, if this firm develops internal economies of scale. From that point of view, it may very well have monopoly power over its products. This would remove it from the threat of competition and lead it to improve the quality of its product in any market.

For African countries with insignificant intra-industry trade, this paper provides a basis for thinking that one of the opportunities to be seized is trade in African timber products. Indeed, the existence of a multitude of wood varieties in Africa suggests that the manufacture of wooden tables (wood from the Sahel, wood from the equatorial forest, etc.) can and should constitute an opportunity for the development of intra-African trade with a view to the construction of the free trade area in Africa.

Furthermore, the study argues that the current trend towards protectionism needs to be corrected as any trade restrictions are costly. Product differentiation, whether horizontal or vertical, offers many more opportunities for gains in international trade.

\section{References}

Aspremont, (d') C., Gabszewicz, J. J., \& Thisse, J. F. (1979). Stability in Competition. Econometrica, 47(5), 1145-1150. https://doi.org/10.2307/1911955

Barberis, N. (2000). Investing for the Long Run when Returns are Predictable. Journal of Finance, LV(1), 225-264. https://doi.org/10.1111/0022-1082.00205

Calmette, M. F. (1994). The role of location of activities in intra-industry trade. Canadian Journal of Regional Science, XVII(3), 351-372.

Chamberlin, E. H. (1933). The Theory of Monopolistic Competition. Harvard University Press.

Dixit, A. K., \& Stiglitz, J. E. (1977). Monopolistic Competition and Optimum Product Diversity. American. Economic. Review, 67, 297-308.

Eaton, B. C., \& Lipsey, R. G. (1978). Freedom of Entry and the Existence of Pure Profit. Economic Journal, 88, 455-69. https://doi.org/10.2307/2232046

Gabszewicz, J. J. (2006). La Différenciation des produits [Product differentiation]. Répères, La Découverte.

Gabszewicz, J. J., \& Thisse, J. F. (1980). Entry (and exit) in a Differentiated industry. Journal of Economic Theory, 22(2), 327-338. https://doi.org/10.1016/0022-0531(80)90046-0

Geweke, J. (1985). Macroeconometric modeling and the theory of representative agents. American Economic Association Papers and Proceeding, 75(2), 206-210.

Grubel, H. G., \& Lloyd, P. J. (1975). Intra-industry trade. London, Mac Millan.

Heckscher, E. (1919). International Trade and Economic History, Findlay R., Rolf G.H. Henriksson, Häken, Lingren and Mats Lundahl.

Hotelling, H. (1929). Stability in Competition. Economic Journal, XXXIX. In Boulding K. et Stigler G. (Éds.), (1953), readings in price theory, Allen and unwin. London. https://doi.org/10.2307/2224214

Kojima, K. (1970). Towards a Theory of Agreed Specialization: The Economics of Integration in "Induction, Growth and Trade" Essays in Honour of Sir Roy Harrod. Oxford.

Krugman, P. R. (1979). Increasing returns, monopolistic competition, and international trade. Journal of International Economics, 9(4), 469-479. https://doi.org/10.1016/0022-1996(79)90017-5 
Lancaster, K. J. (1966). A New Approach to Consumer Theory. Journal of Political Economy, 74(2), 132-157. https://doi.org/10.1086/259131

Lancaster, K. J. (1975). Socially Optimal Product Differentiation. American Economic Review, 65, 567-585.

Lancaster, K. J. (1979). Variety, Equity and Efficiency. Columbia University Press. https://doi.org/10.7312/lanc94538

Lancaster, K. J. (1980). Intra-industry Trade under Perfect monopolistic Competition. Journal of International Economics, 10. https://doi.org/10.1016/0022-1996(80)90052-5

Lassudrie-Duchêne, B. (1971). La demande de différence et l'échange international [The demand for difference and international exchange]. Economie et Société, juin.

Le Boucher, E. (2019, december 6). Trump a perdu la guerre du protectionnisme [Trump lost the war on protectionism]. Les Echo.

Linder, S. B. (1961). An Essay on Trade and Transformation, Almqvist and Wiksell, Stokholm-Göteborg-Uppsala. New York, Wiley and Sons.

Mekki, R. (2005). Comportement stratégique des firmes et commerce international [Strategic Behaviour of Firms and International Trade], Doctoral thesis in economics, Maine University.

Mucchielli, J. L. (1977). Echange Intra-branche et Echange Intra-firme dans le Commerce International, Note Introductive [Intra-Industry Trade and Intra-Firm Trade in International Trade, Introductory Note], Groupe de Recherche en Economie Internationale, Université de Paris XII, Février.

Mucchielli, J. L., \& Mayer, T. (2005). Economie internationale [International Economy]. Hyper Cours, Dalloz.

Ndo Ndong, J. S. (2000). La faisabilité de l'intégration régionale en Afrique centrale [The feasibility of regional integration in Central Africa]. Africa Knowledge Networks Forum Preparatory Workshop, 17-18 August 2000, Addis-Ababa, Ethiopia.

Negishi, T. (1975). General Equilibrium Theory and International Trade (2nd ed.). North Holland.

Ohlin, B. (1933). International Trade Theory: the Evidence. Harvard Washington Press DC.

Ricardo, D. (1817). Principes de l'Economie Politique et de l'impôt [Principles of Political Economy and Taxation], Trad. fr. Calman Levy, Paris 1970.

Salop, S. C. (1979). Monopolistic Competition with Outside Goods. Bell Journal of Economics, 10, 141-156. https://doi.org/10.2307/3003323

Samuelson, P. A., \& Stolper, W. F. (1941). Protection and Real Wages. the Review of Economic Studies, 9(1), 58-73. https://doi.org/10.2307/2967638

Shaked, A., \& Sutton, J. (1982). Relaxing Price Competition through Product Differentiation. Review of Economic Studies, XLIV. https://doi.org/10.2307/2297136

Shaked, A., \& Sutton, J. (1983). Natural Oligopolies. Econometrica, 71, 1469-1484. https://doi.org/10.2307/1912285

Siroën, J. M. (1991). La Spécialisation Internationale et les Gains de l'échange dans la théorie de la concurrence monopolistique [International Specialization and Exchange Gains in the Theory of Monopolistic Competition]. Revue d'Economie Industrielle, 55, 12-24. https://doi.org/10.3406/rei.1991.1347

\section{Copyrights}

Copyright for this article is retained by the author(s), with first publication rights granted to the journal.

This is an open-access article distributed under the terms and conditions of the Creative Commons Attribution license (http://creativecommons.org/licenses/by/4.0/). 